International Journal of Instruction e-ISSN: 1308-1470 • www.e-iji.net

Article submission code: 20201014022258

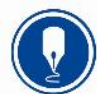

October $2021 \bullet$ Vol.14, No.4

p-ISSN: 1694-609X

pp. $427-438$

Received: 14/10/2020

Revision: 21/03/2021
Accepted: 15/04/2021

OnlineFirst: 08/08/2021

\title{
Optimizing Transformational Leadership Strengthening, Self Efficacy, and Job Satisfaction to Increase Teacher Commitment
}

\section{Sri Setyaningsih}

Dr., Postgraduate School, Pakuan University, Indonesia, sri_setya@ unpak.ac.id

\section{Widodo Sunaryo}

Postgraduate School, Pakuan University, Indonesia,widodos.unpak@yahoo.com

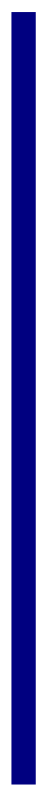

Based on the problem that the teacher's commitment to the profession is still not as expected, this study aims to find ways to improve teacher commitment to the profession by examining the influence of transformational leadership, self-efficacy, and job satisfaction. The methodologies used are the Path method and Sitorem method. The study population was 1307 Non-Civil Servant, middle school teachers in Cirebon District, Indonesia with a research sample of 136 teachers. The NonCivil Servant middle school teachers are teachers who are not paid by the government but by the foundation. The results showed that the Teacher's Commitment to the Professionals could be increased through strengthening Transformational Leadership, Self-Efficacy, and Job Satisfaction. The strengthening of variables is carried out by correcting the weak indicators based on Sitorem's analysis, so that the priority order for handling the improvement of indicators is carried out as follows: 1. Strength of self-confidence, and 2. Announcement of self-confidence for Self-Efficacy variables, 3. Salary received, 4 Promotion, and 5. Supervision of Supervisors for the Job Satisfaction variable, 6. The job itself, 7. Surviving in the Organization, and 8. Establishing Professional Values for the Teacher Commitment variable towards the Profession. This main contribution of our research to provide empirical evidence that the Path Analysis and Sitorem Analysis methods are very good to be used to analysed the factors that influence the strengthening of the Teacher's commitment to his professionalism.

Keywords: commitment to the profession, transformational leadership, self-efficacy, job satisfaction, sitorem method

\section{INTRODUCTION}

The issue of teacher job satisfaction is a leadership challenge in educational institutions in Indonesia has been a concern for a long time. Lack of access to higher education, in the past, led to the privatization of higher education in response to increasing demand. Despite efforts by the Indonesian government to improve tertiary education, much remains to be achieved in teacher satisfaction. This is demonstrated from studies that

Citation: Setyaningsih, S., \& Sunaryo, W. (2021). Optimizing transformational leadership strengthening, self efficacy, and job satisfaction to increase teacher commitment. International Journal of Instruction, 14(4), 427-438. https://doi.org/10.29333/iji.2021.14425a 
have revealed high levels of teacher satisfaction and learning, in the school system where transformational leadership is applied. Therefore, how important transformational leadership is to job satisfaction, management style and performance (Yulius et al. 2019; Choi et al. 2016). Transformational leadership and satisfied followers remain a major problem for educational institutions in Indonesia, with limited financial and academic resources if they want to remain academically competitive and financially viable. The teacher's commitment to the profession is the teacher's behaviour related to professional values, ethics, beliefs, willingness to do good work, and the desire to maintain membership in the educational organization where he works. If the teacher's commitment is low, they will work at will so that learning becomes disrupted. As a result, students receive less optimal learning, so that if they become graduates, the quality is not as expected by the educational goals in Indonesia (Yulius et al. 2019).

Several previous studies related to the problem of transformational leadership, selfefficacy, and job satisfaction in an effort to increase teacher's commitment to the profession. Jiang et al. (2017) and Paracha et al. (2012), examined the effect of transformational leadership on employee performance. His research aims to find out the level of influence of transformational leadership on employees' ongoing performance, as well as the role of conflict resolution efforts by involving neutral third parties in organizational members. A total of 389 questionnaires were taken from respondents, and then analysed using structural equation modelling. The analysis shows that the ongoing performance of employees is significantly influenced by transformational leadership. The analysis also shows that conflict resolution by involving a neutral third party in the organization's members also significantly plays an important role. Similar research has also been carried out by Damirch et al. (2011), Choi et al. (2016), Buil et al. (2018), and Iqbal et al. (2020).

Köseoglu (2015), conducted a study related to self-efficacy in school students by using multivariate analysis of co-variance (MANCOVA). The analysis shows that students who have low levels of self-efficacy believe that intelligence is innate and cannot be changed. Conversely, students who have high levels of self-efficacy, prefer mastery goals, prefer to face challenges that provide new knowledge, always show good performance and surpass others. Research has also found the fact that students who have high levels of self-efficacy are able to analyse and control impulses, and are able to develop in facing challenges so that they excel academically. Köseoglu said that for teachers who prefer to focus on the goal of increasing academic achievement in order to always strengthen self-efficacy. Research related to self-efficacy has also been carried out including by Safaria and Ahmad (2013) \& Bakker et al. (2017).

Basu (2016), examines professional commitment and job satisfaction among secondary school teachers. His research was conducted on 98 high school teachers in the Bareilly district. The commitment scale for teachers developed by Kaur et al., And the job satisfaction questionnaire developed by Kumar \& Mutha were used in data collection. The collected data were analysed based on the mean, standard deviation, t-test, and moment correlation of Pearson products. Based on the investigation revealed that sex and teaching experience that has long spoken significantly influence the professional 
commitment of secondary school teachers, while the type of school significantly does not affect the professional commitment of secondary school teachers. In addition, gender, type of school, and teaching experience significantly also affect the level of job satisfaction of secondary school teachers. Also professional commitment and job satisfaction of secondary school teachers turned out to have a strong positive correlation. Such studies have also been carried out by Colquitt et al. (2013), Bashir (2017), Yosof et al. (2016), Farooqi et al. (2015), \& Cherkowki (2012).

Leadership is an important aspect in management because it has a big influence on a series of activities, which can be a trigger for the achievement of organizational goals. For this reason experts and practitioners in the field of leadership, propose effective leadership in organizations to encourage the acceleration of change to ensure the achievement of organizational output (Colquitt et al. 2013; Gibson et al. 2012). Basically, it has become very necessary in an increasingly urgent and changing environment with demands from all walks of life, so that organizations have responsibility for their continued existence (Robbins and Judge, 2013; Kinicki et al. 2010). Educational institutions as organizations have not been freed from such pressure.

Transformational leadership behaviour, represents a very effective leadership style and plays a major role in realizing output in all educational institutions. Because transformational leadership is intended as a formal collegial leadership model in educational institutions. Transformational leadership is able to motivate and inspire followers to reach even beyond their ideals, and in the process of developing the capacity, quality, and actuality of the followers themselves (Yulius et al. 2019; Jiang et al, 2017).

Referring to the goal of building a shared vision, transformational leaders always pay attention and respond to the needs of followers, by empowering and aligning the goals and objectives of the organization with followers. Therefore, a high level of follower satisfaction is said that transformational leadership behaviour is positively correlated with higher performance, greater organizational commitment, and higher job satisfaction among teachers (Dionne et al. 2004; Damirch et al. 2011). Some research confirms that transformational leadership behaviour is positively correlated with higher performance, greater organizational commitment, and higher job satisfaction among employees. In this view, educational institutions need transformational leaders to motivate teachers to increase job satisfaction and high learning within the existing system of educational institutions themselves (Kallapadee et al. 2017; Ubaidillah et al. 2019).

Self-efficacy, believing one's ability and strength to learn and excel, is the main characteristic of the teacher's success in representing a special individual, as someone who is confident in one's ability to manage and realize the actions needed, to produce achievements set based on self-efficacy classification into categories. One of them is academic self-efficacy and shows that it reflects the ability perceived by the teacher in relation to the tasks expected of the teacher in the academic domain (Köseoglu, 2015; Safaria and Ahmad, 2013). To understand the relationship between academic selfefficacy and cognitive abilities, it may be necessary to study cognitive approaches, resource management, relevant intelligence theories, and achievement of goals. 
Someone who has self-efficacy will effectively handle their resources, believe that intelligence is flexible, pursue mastery goals rather than performance, and therefore can display better academic performance.

Based on the description above, in this paper a study of optimization of strengthening transformational leadership, self-efficacy, and job satisfaction in an effort to increase teacher's commitment to the profession. This study aims to find ways to increase teacher commitment to the profession by testing the strength of the influence of other variables on the commitment of the teacher profession. Other variables are transformational leadership, self-efficacy, and job satisfaction. The results of an initial survey of 30 private junior high school (SMP) teachers in Cirebon District showed that the commitment of teachers to the profession was still not as expected. It means "das Sein" is not like "das Sollen". Therefore, the teacher's commitment to the profession is interesting to learn. Therefore, this research is considered very important to be done.

\section{Literature Review}

\section{Teacher's Commitment to the Profession}

According to Sezgin and Cahit (2012), commitment to one's work is related to the profession and career, which is defined as the relative strength of identification and involvement in a particular profession, as well as the willingness to exert effort on behalf of the profession and the desire to maintain membership in it. The indicators are a) affective commitment, i.e. one's emotional attachment to his work, b) normative commitment, one's sense of obligation to remain in work, and c) continuing commitment which involves an individual's assessment of the costs associated with leaving his job.

Farooqi et al (2015), states that commitment to the profession is the best effort and shows integrity at work. Every profession must have its own set of ethics and ideologies that guarantee its effectiveness and integrity. So when a teacher enters his profession as an educator, the teacher must accept existing norms and ethics. There are three types of professional commitments, namely 1) affective professional commitment, 2) ongoing professional commitment, and 3) normative professional commitment. Affective profession commitment is strong emotional affection for the profession and the organization. In teaching the teacher tells the teacher's emotional association in recognition and involvement in work.

The behaviours shown include having a strong motivation not to leave work, engaging in a selfless learning process and full of dedication to face the challenges. Commitment of a continuing profession that is convinced that the profession owned can meet the needs of his life in terms of financing his life so that he will continue to exist to continue his career and fulfil the ethics of his profession. Commitment to the normative profession is a commitment to always maintain the stability or togetherness between the morals of society and their profession accompanied by a sense of responsibility to uphold values.

According to Cherkowski (2012), teacher commitment is broadly conceptualized as a desire to continue and a commitment to grow and learn in the professional community of 
colleagues. The teacher's commitment to the profession is related to a sustainable learning community. This means that the emergence of a sustainable learning community in school communities is inseparable from how the teacher's commitment to the profession.

Based on the explanation above, it can be synthesized that the teacher's commitment to the profession is the behaviour of the teacher and his profession related to professional values, ethics, beliefs, willingness to do good work, and maintaining membership in it. The indicators are 1. Persist in the organization, 2. Strength in dealing with work, 3. Motivation in doing work, 4. Implementation of work obligations, and 5. Enforcement of professional values.

\section{Transformational leadership}

Colquit et. al (2013) states, that transformational leadership is leadership that involves the inspiration of all its members to commit to a common vision that gives meaning to the development of their own potential and some problems from a new perspective. The indicators are: a) Idealized influence or charisma, b) intellectual stimulation, c) individualized consideration, and d) inspirational motivation.

The transformational leadership is leadership that changes employees to pursue organizational goals beyond personal interests (Colquitt et al., 2010). Transformational leaders will try to influence, mobilize, and develop their leadership to others. The indicators are: a) that is the influence on subordinate thought patterns, b) intellectual stimulation, c) individualized consideration, and d) inspirational motivation.

Buill et al (2013), state that transformational leadership is an activity of stimulating and inspiring followers to achieve extraordinary results and in the process of developing their own leadership capacity. The indicators are: a) idealized influence, ie leadership acts as a role model or role model, b) intellectual stimulation, that is, leadership stimulates people to be creative and innovative, c) individualized consideration, that is, leaders develop people by creating a supportive environment, d) inspirational motivation, i.e. the leader creates a clear picture of the state of the future with optimism.

Based on the explanation above, it can be synthesized that transformational leadership is the behaviour of leaders who change the personal values of followers to believe, be amazed, be loyal, respectful, and set aside their personal interests to support the organization's vision and goals to be achieved well. The indicators are 1. Ideal influence, 2. Inspirational motivation, 3. Intellectual stimulation, 4. Individual development.

\section{Self-Efficacy}

According to Gibson et al. (2012) Self-efficacy is the belief that a person can do his work in certain situations. The indicators are: a) the magnitude of the difficulty level of the task that a person believes can be achieved, b) Strength, refers to beliefs about the magnitude as strong or weak, c) Generality, to what extent the expectations are generalized in all situations. 
According to Ivancevich et al (2010), self-efficacy is the belief that someone can perform well in certain situations. The indicators are: a) Motivation to engage in behaviour that will help them perform well, b) To learn more and transfer learning to improve their work performance, and c) direct (themselves) to a higher level of goal setting, and d) performance.

Robbins (2013) states that self-efficacy refers to the individual's belief that he is capable of doing a task. Whereas Gibson et al (2012), stated that self-efficacy is the belief that we have sufficient skills in certain situations.

Based on the description of some of the above theories can be synthesized that selfefficacy is one's belief in the ability he has to complete his task successfully.

\section{(ELM) Job Satisfaction}

According to Gibson et al (2012), job satisfaction is an individual's attitude towards his job that comes from his perception of his work. The indicators are a) Salaries and salaries received, b) Conditions of work, c) facilities and infrastructure, d) Opportunity for promotion, e) Supervision of leadership, and f) Relations with colleagues.

In line with the above opinion, Colquitt et al (2013), stated job satisfaction is an emotional condition of an individual that arises from an assessment of his work or experiences at work. There are 5 desired factors or indicators: a) Salary, b) Promotion, c) Supervision of supervisor, d) Relationship with coworkers, and e) The job itself.

According to Wright and Cropanzano (2000), that job satisfaction is an internal state expressed by effectively and / or cognitively evaluating an experienced job with several levels of likes or dislikes. Indicators of job satisfaction are: a) the level of satisfaction with the job itself, b) the level of satisfaction with coworkers and c) the level of satisfaction with supervision.

Based on the opinion above, it can be synthesized that job satisfaction is an emotional condition of an individual that arises from his assessment of work and his experience in work.

\section{METHOD}

The methodology used in this study is quantitative method, namely the Path Analysis Method and the Sitorem Method from Hardhienata (2017). Path analysis method is used to test whether the variables studied are Transformational Leadership, Self-Efficacy, and Job Satisfaction have a positive effect on the Professional Commitment of Lecturers. While the Sitorem Method is used for the analysis of research indicators which will then be used to establish recommendations and action plans.

This research was conducted at State Junior High Schools in Cirebon Regency, Indonesia. State Junior High Schools amounting to 80 schools which are divided into 8 region and spread in 40 sub-districts in Cirebon Regency. This research uses quantitative research type that is the type of research that emphasizes testing theories through measurement of research variables with numbers and requires data analysis with 
statistical procedures. Measurement tools in the form of a questionnaire, data obtained in the form of answers from respondents, namely teachers and principals to the questions asked. The study population was 1458 non-PNS public junior high school teachers in Cirebon Regency.

Sampling was carried out using random sampling and the William G Cochran formula (Velmurugan, 2016; Setyaningsih et al. 2019):

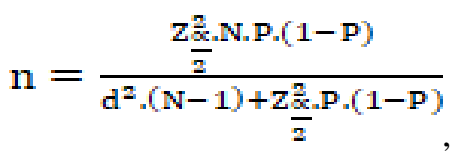

where $\mathrm{n}=$ Number of selected samples used as respondents; $\mathrm{N}=$ Total population of non- Government employees (non-PNS) teachers who meet the sample criteria, namely non-PNS teachers who are in State Junior High Schools, have a service life of between $1-20$ years; $\mathrm{P}=$ The proportion of teachers in the total population is $1307 / 1458=0.89 ; \mathrm{d}$

$=$ The level of alleged error used is $\propto=5 \%=0.05 ; \mathrm{Z}_{\propto / 2}=$ The distribution of random variables is $95 \%$ (from the two-way $\mathrm{Z}$ table $=1.96$ ). From the calculations using the formula (1) above obtained 136 Research Samples.

The instrument is made from research indicators that will be identified. Each indicator is broken down into indicator details and then used to make instrument items. The instrument items that have been made are then tested for their validity and reliability. The tested instruments are then distributed to respondents to be answered and filled out. Data collected from these respondents were then analysed using the path analysis method to determine the strength of influence of the independent variables on the dependent variable.

The Sitorem Analysis is then performed to determine the recommendations of the research results and prioritize the handling of indicators. The basic considerations used to reduce recommendations and priority order for handling these improvements include 3 (three) criteria, namely: a). The power of influence between the independent variable and the dependent variable. b). The priority order of indicators of the variables studied is based on expert judgment. c). Indicator values obtained from the results of research in the field. From this analysis Sitorem will produce the following: a). Indicators that are already good, so it is recommended to be maintained, and b). Indicators are not good yet, so it is recommended to be corrected in order of priority for improvement.

This priority order of improvement is important because in general the organization's resources are limited, so handling improvements must be done in stages in accordance with the organization's capabilities.

\section{FINDINGS AND DISCUSSION}

After the data from the research respondents were collected then a path analyst was conducted with the following results: There was a positive influence of 
Transformational Leadership on Professional Commitment with a path coefficient $\rho \mathrm{y} 1=0.160$. There was a positive effect of Self-Efficacy on Professional Commitment with path coefficient $\rho$ y $2=0.400$. There is a positive influence of Job Satisfaction on Professional Commitment with path coefficient $\rho$ y $1=0.250$.

Furthermore, the indicator value was calculated using Eq. (2) to determine whether the indicator is in good condition so that it remains to be maintained or is still weak so it needs to be improved. The indicator was calculated based on the respondent's answer to the instrument.

Table 1

Calculation of respondent's answer to the instrument.

\begin{tabular}{lllll}
\hline Assessment & Instrument 1 & Instrument 2 & $\ldots$ & Instrument $\mathrm{m}$ \\
\hline Respondent 1 & Score $(1,1)$ & Score $(1,2)$ & $\ldots$ & Score $(1, \mathrm{~m})$ \\
Respondent 2 & Score $(2,1)$ & Score $(2,2)$ & $\ldots$ & Score $(2, \mathrm{~m})$ \\
$\ldots$ & $\ldots$ & $\ldots$ & $\ldots$ & $\ldots$ \\
Respondent $\mathrm{r}$ & Score $(\mathrm{r}, 1)$ & Score $(\mathrm{r}, 2)$ & $\ldots$ & Score $(\mathrm{r}, \mathrm{m})$ \\
& Amount 1 & Amount 2 & $\ldots$ & Amount m \\
\hline
\end{tabular}

For example, $\mathrm{I}$ is an indicator that has a number of $\mathrm{m}$ instruments with respondents who fill the instruments as much as $r$ as shown in Table 1, then the value of the NI indicator is calculated by the formula:

$\mathrm{NI}=($ Amount $1+$ Amount $2+\ldots+$ Amount $\mathrm{m}) / \mathrm{m}$

For positive instruments with a scale from 1 to 5 , the classification was the indicator in good condition if $\mathrm{Ni} \geq 4$ and the indicator with a value of $\mathrm{Ni}<4$ fall into bad condition category and still need improvement.

Calculation of indicators in accordance with Formula 5.1 above produced the following values: Transformational Leadership Variables: Ideal Influence (4.1), Inspirational Motivation (4.2), Intellectual Stimulation (4.2), and Individual Development (4.1).

Self-efficacy variables: level of confidence (4.02), generality (3.90), and strength (3.78).

Job Satisfaction Variables: Salary (3.13), Promotion (3.51), Supervision Supervisor (3.6), Work itself (3.52), and Relationship with co-workers (4.14).

Teacher Commitment Variables to the Profession: Persist in the organization (3.87), Strength in carrying out the work (4.12), Motivation in carrying out the work (4.08), Obligation to the job (4.29), and Enforcement of professional values (3.85).

Next, determining the order of priority in handling indicators improvement with assessments were carried out by Experts, the results were as follows: Transformational Leadership Variables: 1. Inspirational motivation (28\%), 2. Ideal influence (26\%), 3. Intellectual stimulation ( $24 \%$ ), 4. Individual development ( $22 \%$ ).

Self-efficacy variables: 1. Strength (43\%), 2. Generality(32\%), 3. Confidence level $(25 \%)$. 
Job Satisfaction Variables: 1. Salary (26\%), 2. Promotion (23\%), 3. Supervision of supervisors (19\%), 4. Work itself (17\%), 5. Relationships with colleagues (15\%).

Teacher Commitment Variables to the Professional: 1. Strength in doing work (24\%), 2. Survive in the organization $(22 \%), 3$. Obligations in work $(21 \%), 4$. Motivation in doing work (17\%), 5. Professional value enforcement (16\%).

Based on the results of path analysis, calculation of indicator values, and priority ranking of indicators as outlined above then it can then be arranged the optimal handling for strengthening the variables of Transformational Leadership, Self-Efficacy, and Job Satisfaction in an effort to increase Teacher Commitment to Profession as shown in Table 2.

Table 2

Sitorem analysis results

\begin{tabular}{|c|c|c|}
\hline \multicolumn{3}{|l|}{ PROFESSIONAL COMMITMENT } \\
\hline Indicators in Initial State & Indicators after Weighting by Expert & Indicator Value \\
\hline 1. Survive in organization & 1st Strength at works $(24 \%)$ & 4.12 \\
\hline 2. Strength at work & 2nd Survive in organization $(22 \%)$ & 3.87 \\
\hline 3. Motivation in work & 3rd Obligation in work $(21 \%)$ & 4.29 \\
\hline 4. Obligation in works & 4th Motivation in work (17\%) & 4.08 \\
\hline 5. Enforcements of Profession & 5th Enforcement of Profession (16\%) & 3.85 \\
\hline \multicolumn{3}{|c|}{ TRANSFORMATIONAL LEADERSHIP (r41 = 0.160) (III) } \\
\hline Indicators in Initial State & Indicators after Weighting by Expert & Indicator Value \\
\hline 1. Ideal influences & 1st Inspirational motivation $(28 \%)$ & 4.20 \\
\hline 2. Inspirational motivation & 2nd Ideal influences $(26 \%)$ & 4.10 \\
\hline 3. Intellectual stimulation & 3rd Intellectual stimulation $(24 \%)$ & 4.20 \\
\hline 4. Individual development & 4th Individual development ( $22 \%)$ & 4.10 \\
\hline \multicolumn{3}{|l|}{ SELF EFICACY $(\mathrm{r} 42=0.400)(\mathrm{I})$} \\
\hline Indicators in Initial State & Indicators after Weighting by Expert & Indicator Value \\
\hline 1. Confidence level & 1st Strength of faith $(43 \%)$ & 3.78 \\
\hline 2. Generality & 2nd Generality $(32 \%)$ & 3.90 \\
\hline 3. Strength of faith & 3rd Confidence level $(25 \%)$ & 4.02 \\
\hline \multicolumn{3}{|c|}{ JOB SATISFACTION (r43 = 0.250) (II) } \\
\hline Indicators in Initial State & Indicators after Weighting by Expert & Indicator Value \\
\hline 1. Salary & 1st Salary $(26 \%)$ & 3.13 \\
\hline 2. Promotion & 2nd Promotion $(23 \%)$ & 3.51 \\
\hline 3. Management supervision & 3rd management supervision (19\%) & 3.60 \\
\hline 4. Job itself & 4 th Job itself $(17 \%)$ & 3.52 \\
\hline $\begin{array}{l}\begin{array}{c}\text { 5. Relationship with co- } \\
\text { workers }\end{array} \\
\end{array}$ & 5th Relationship with co-workers $(15 \%)$ & 4.14 \\
\hline \multicolumn{3}{|c|}{ SITOREM ANALYSIS RESULTS } \\
\hline \multicolumn{2}{|c|}{ Priority order of indicators to be strengthened } & maintained \\
\hline 1st Strength of faith & & Confidence level \\
\hline \multicolumn{2}{|l|}{ 2nd Generality } & vorkers \\
\hline 3rd Salary & Inspirational motiv & \\
\hline 4th Promotion & Ideal influences & \\
\hline 5th Management supervision & Intellectual stimula & \\
\hline 6th Job itself & Individual develop & \\
\hline 7th Survive at organization & Strength at work & \\
\hline 8th Enforcement of profession & Obligation in work & \\
\hline & Motivation in worl & \\
\hline
\end{tabular}




\section{CONCLUSION}

Based on the results of the discussion described above it can be concluded that the Commitment of Teachers to the Profession can be increased through Strengthening Transformational Leadership, Self-Efficacy, and Job Satisfaction. The optimal results for strengthening Transformational Leadership, Self-Efficacy, and Job Satisfaction in an effort to increase Teacher Commitment to the Profession are as follows:

The indicator is in good condition and remains to be maintained: 1). Self-Efficacy Variables: The level of confidence to be able to successfully carry out the task well. 2). Job Satisfaction Variable: Relationship with Colleagues. 3). Transformational Leadership Variables: Inspirational Motivation, Ideal Effects, Intellectual Stimulation, and Individual Development. and 4). Teacher Commitment Variables: Strength in doing work, and motivation in doing work.

Indicators that are still weak and need to be corrected in the order of priority for handling improvements are as follows: Self-Efficacy Variables: 1). Strength of belief, and 2). Publicity of belief. Job Satisfaction Variables: 1). Salary Amount, 2). Promotion Opportunities, 3). Supervisor Supplement, and 4). The Job itself. Transformational Leadership Variables: None. Teacher Commitment Variables: 1). Persist in the Organization, and 2. Professional Value Enforcement .

In order for the above recommendations to have a maximum impact, it is recommended that the implementation of strengthening Transformational Leadership, Self-Efficacy, and Job Satisfaction in an effort to increase Teacher's Commitment to the Profession be carried out in the order of priorities that have been set.

\section{REFERENCES}

Bakker, A. B., \& van Woerkom, M. (2017). Flow at work: A self-determination perspective. Occupational Health Science, 1(2), 47-65.

Basu, S. (2016). Professional commitment and job satisfaction among secondary school teachers. Educational Quest-An International Journal of Education and Applied Social Sciences, 7(3), 255-259.

Bashir, L. (2017). Job satisfaction of teachers in relation to professional commitment. The International Journal of Indian Psychology, 4(4), 1-8.

Buil, I., Martínez, E., \& Matute, J. (2019). Transformational leadership and employee performance: The role of identification, engagement and proactive personality. International Journal of Hospitality Management, 77, 64-75.

Cherkowski, S. (2012). Teacher commitment in sustainable learning communities: A new "ancient" story of educational leadership. Canadian Journal of Education, 35/1, 56-68.

Choi, S. L., Goh, C. F., Adam, M. B. H., \& Tan, O. K. (2016). Transformational leadership, empowerment, and job satisfaction: the mediating role of employee empowerment. Human resources for health, 14(1),73-85. 
Colquitt, J., Lepine, J. A., Wesson, M. J., \& Gellatly, I. R. (2011). Organizational behavior: Improving performance and commitment in the workplace (Vol. 375). New York, NY: McGraw-Hill Irwin, pp. 1-641.

Damirchi, Q. V., Rahimi, G., \& Seyyedi, M. H. (2011). Transformational leadership style and innovative behavior on innovative climate at SMES in Iran. Kuwait Chapter of Arabian Journal of Business and Management Review, 33(832), 1-9.

Dionne, S. D., Yammarino, F. J., Atwater, L. E., \& Spangler, W. D. (2004). Transformational leadership and team performance. Journal of organizational change management, 17(2), 177-193.

Farooqi, M. T. K., Iqbal, A., \& Tahir, M. S. (2015). Relationship of organizational climate with teachers' job satisfaction. Journal of Educational Research, 18(1), 56-63.

Gibson, J., Ivancevich, J., \& Konopaske, R. (2011). Organizations: Behavior, structure, processes. McGraw-Hill Higher Education, pp. 1-400.

Hardhienata, S. (2017, January). The development of scientific identification theory to conduct operation research in education management. In IOP Conference Series: Materials Science and Engineering (Vol. 166, No. 1, p. 012007). IOP Publishing.

Iqbal, K., Fatima, T., \& Naveed, M. (2020). The Impact of Transformational Leadership on Nurses' Organizational Commitment: A Multiple Mediation Model. European Journal of Investigation in Health, Psychology and Education, 10(1), 262-275.

Jiang, W., Zhao, X., \& Ni, J. (2017). The impact of transformational leadership on employee sustainable performance: The mediating role of organizational citizenship behavior. Sustainability, 9(9), 1567.

Kallapadee, Y., Tesaputa, K., \& Somprach, K. (2017). Strengthening the Creative Transformational Leadership of Primary School Teachers. International Education Studies, 10(4), 179-186.

Kinicki, Angelo and Williams, Brian K., 2010, Management: A Practical Introduction. New York: McGraw-Hill, pp 1-430.

Köseoglu, Y. (2015). Self-Efficacy and Academic Achievement--A Case from Turkey. Journal of Education and Practice, 6(29), 131-141.

Paracha, M. U., Qamar, A., Mirza, A., Hassan, I. U., \& Waqas, H. (2012). Impact of leadership style (transformational \& transactional leadership) on employee performance $\&$ mediating role of job satisfaction. Study of private school (educator) in Pakistan. Global Journal of Management and Business Research, 12(4), 55-64.

Robbins, Stephen P. and Timothy A Judge, T.A. 2013. Organizational Behavior. English: Pearson Educational Limited, pp 1-311.

Safaria, T., \& Ahmad, A. (2013). Effects of Self-Efficacy on Students Academic Performance. Journal of Educational, Health and Community Psychology, 2(1), 24809. 
Setyaningsih, S., Ishlah, M. S. N., \& Hardhienata, S. (2019). Optimization of Enhancement of Lecturer Professional Commitment using Path Analysis and Sitorem Method. International Journal of Recent Technology and Engineering, 8, 121-28.

Sezgin, M., \& Ağar, C. C. (2012). Impact of affective organizational and occupational commitment on job satisfaction: PR specialists in metropolitan municipalities. International Journal of Business and Commerce, 2(2), 21-35.

Ubaidillah, M., Imron, A., Wiyono, B. B., and Arifin, I. (2018). Innovation Leadership in Improving the Quality of Education. International Journal of Mechanical Engineering and Technology, 9, 1288-99.

Velmurugan. (2016). Job Satisfaction of Teachers. Journal of Research in Humanities and Social Sciences, 1, 20-3.

Wright, T. A., \& Cropanzano, R. (2000). Psychological well-being and job satisfaction as predictors of job performance. Journal of occupational health psychology, 5(1), 84.

Yulius, E. R., Ibrahim, B., Nyoman, D. S., \& Imbron, A. (2019). Principal's Transformational Leadership In Strengthening Character Education Based On Teaching Values And Dimensions Lonto Leok, Manggarai Community, West Flores - Indonesia. IOSR Journal of Research \& Method in Education, 9, 63-79.

Yusof, H., Osman, M. N. A. H., \& Noor, M. A. M. (2016). School culture and its relationship with teacher leadership. International Journal of Academic Research in Business and Social Sciences, 6(11), 272-286. 